\title{
Molecular Basis of Hypertension: A Systematic Review on the Role of Metal Ions for Increase Prevalence of Hypertension in India
}

\author{
Kshetrimayum Birla Singh \\ Department of Zoology, Pachhunga University College, Mizoram University, Aizawl, India \\ Email: birla.kshetri@gmail.com
}

Received 28 April 2016; accepted 25 June 2016; published 28 June 2016

Copyright (C) 2016 by author and Scientific Research Publishing Inc.

This work is licensed under the Creative Commons Attribution International License (CC BY). http://creativecommons.org/licenses/by/4.0/

(c) (i) Open Access

\begin{abstract}
Metal ions played critical role in regulation of hypertension (HT) or blood pressure (BP). The physiological roles of metals commonly present in the diet in the etiology of HT need to be reviewed as recent survey on the metal status in the various vegetable and meat food stuffs commonly consumed by living population in India revealed an imbalance in its level. Higher levels of zinc (Zn) in diet is observed to increase the BP by various mechanisms including oxidative stress through decreased activity of superoxide dismutase (SOD) enzyme, increasing levels of angiotensin converting enzyme (ACE) and aldosterone and by causing acidification due to change in the levels of $\mathrm{H}^{+}$, $\mathrm{Na}^{+}, \mathrm{K}^{+}$and $\mathrm{Ca}^{2+}$ ions in the blood. High level of copper (Cu) and low level of magnesium $(\mathrm{Mg}$ ) and manganese (Mn) in the blood is also associated with HT through various mechanisms like elevation of chronic inflammation, accelerating $\mathrm{Na}^{+}$pump of cell membrane and by disturbing lipid metabolism in the body. An epidemiological study conducted in the population of Manipur, India consuming $\mathrm{Zn}$ rich diet reveals significant disparities in distribution of the metals in the blood of the hypertensive (HTS) patients as compared to the normotensives (NT) control and thus indicates that the change in body metal homeostasis may be a triggering factor for the development of HT in this population and corroborate the reports of published literatures. The role of the metals variations in the body and their possible involvement in HT is reviewed and discussed in this paper.
\end{abstract}

\section{Keywords}

$\mathrm{Zn}, \mathrm{Cu}, \mathrm{Mg}$, Mn, Hypertension, India

How to cite this paper: Singh, K.B. (2016) Molecular Basis of Hypertension: A Systematic Review on the Role of Metal lons for Increase Prevalence of Hypertension in India. Journal of Biosciences and Medicines, 4, 12-22. 


\section{Introduction}

Hypertension is an important public health problem all over the world and is one of the biggest health challenges in the $21^{\text {st }}$ century. Although the condition is common and usually asymptomatic, it often leads to lethal complications if remain untreated [1]. Global Burden of Disease study has reported HT as the $4^{\text {th }}$ contributor to premature death in developed countries and the $7^{\text {th }}$ in the developing countries with India portray a grim picture as the $17.8 \%$ of the world's population reside in India [2] [3]. It has been reported that HT is directly responsible for $57 \%$ of all stroke deaths and $24 \%$ of all coronary heart disease (CHD) deaths only in India [4]. The higher the individual's BP, the greater are the risks for developing heart disease, stroke, renal failure and peripheral vascular diseases and thus is the major factor in increasing the complications for cardiovascular and cerebro-vascular diseases leading to morbidity and mortality [5].

The involvement of metals especially major metals such as sodium $(\mathrm{Na})$, potassium $(\mathrm{K})$ and calcium $(\mathrm{Ca})$ in the aetiology, prevention and treatment of essential HT has received much attention in the last several years. However, little attention has been given and not fully elucidated in the role of inorganic trace metals in the aetiology of HT [6]. It has been reported that in the body the individual metals react directly and indirectly in a variety of metabolic and structural activities known to participate in the BP regulation [7]. This significance of trace metals is clearly understood from the fact that slight changes in their concentration in human body trigger some kind of complications which later on develop into life threatening diseases [8]. It is also well established that trace metals play vital role as activators or inhibitors of various enzymatic reactions by competing with other metals/proteins for binding sites, by influencing the permeability of cell membranes, or through other mechanisms [9]. Trace metals are also recognized as essential mediators for the development and progression of cardiovascular disease, although there is no concrete evidence for the direct relationship between the metals and progression of the disease [10]. Contradictory results have been published about the relation between $\mathrm{Cu}$, Se, $\mathrm{Zn}$, Mn with HT [11] [12]. Edward et al., in 1993 [13] confirmed the association of metals with the symptoms of hypertension such as headache which led to the determination of electrolytes and some metals in blood plasma as well as their extra cellular and intracellular concentrations. Further, the role of some physiologically important metals such as $\mathrm{Zn}, \mathrm{Cu}, \mathrm{Mg}$ and $\mathrm{Mn}$ in the serum has been elucidated in maintaining BP [14] [15]. Their imbalance is observed to be associated with an increased risk of HT attributed to the modification of their homeostasis in essential HT [16]-[18]. In HT patients, with or without complication, hyperzincemia, hypocuperamia, hypermagnesemia, hypermangnesemia with hyperzincuria, hypercupereuria, hypermagneuria and hypermanganeura are observed [19]-[25]. A positive and negative correlation of HT with serum Zn and Cu levels in essential $\mathrm{HT}$, increased levels of $\mathrm{Zn}, \mathrm{Mg}$ and $\mathrm{Mn}$ but decreased levels of $\mathrm{Cu}$ in HT patients and increased serum Zn and Zn/Cu ratios in HT and CHD group vs healthy subjects have been seen to occur [14] [15] [26] [27]. A number of studies show a high Zn:Cu ratio in the diet lead to an elevation in systemic BP in rats fed a high Zn diet [28] and they later developed of CHD [29] [30]. Moreover, the risk of Cu deficiency increased in humans when molar ratio of $\mathrm{Zn}$ to $\mathrm{Cu}$ was increased in the diet which also resulted in hypercholesterolemia, hypertension and impaired prostaglandin metabolism [30] [31]. Thus, controversies still exist over the therapeutic use of these metals to alter their status in the blood in order to maintain HT. In view of the increased prevalence of HT in Indian population and critical role play by metal ions in the aetiology of HT, the role of metal variations and their possible involvement in the HT is systematically reviewed and discussed with reference to a short study on the status of metals in the serum and urine of HTS patients in an Indian population consuming Zn rich diet.

\section{Disparity in Blood Metals ( $\mathrm{Mg}, \mathrm{Zn}, \mathrm{Cu}, \mathrm{Mn}$ ) Status is Linked to Hypertension}

Metals are naturally occurring inorganic elements which are present in very small amounts in the living tissues but are important for the vital processes of life [32]. Metals are involved in a wide range of physiological processes such as prosthetic groups of many proteins, water balance, cofactors of many enzymes etc [33] and thus the regulation of various metallic contents in the body is pre-requisite for their proper functioning [34]. It has been reported that macro and micro metals are known to play a major role in various enzyme reactions directly related to the regulation of BP and indirectly related to generation of oxidative metabolic energy and alterations in blood lipid levels. Disturbances in these metals composition may therefore play a major role in the development and management of essential HT [35]. The contribution of some major metals namely Na, K and Ca to this process has been established both in man through numerous epidemiological surveys and in experimental animals models. Modifications in Ca and Mg metabolism observed in certain types of HT in man have led to the 
suggestion that their imbalance could contribute to the appearance of long term variations in BP due to their critical role in cardiac and vascular physiology. It has been reported that Mg functions particularly in conjunction with other nutrients for BP regulation [36]. However, studies performed on serum and blood Mg levels in HT patients are controversial [25]. The serum concentration of Mg was significantly lowered in HTS as compared with NT group and this may attributed to increased risk of cardiovascular damage including HT, coronary constriction and occlusion and sudden death. The hypomagnesemia observed in HTS patients may be as a result of low $\mathrm{Mg} / \mathrm{Ca}$ ratio which has been found to stimulate the release of catecholamines, the auto-oxidation of which yield free radical which lowers tissue Mg levels. Hypomagnesaemia thus result increase in BP as it favours release or formation of factors that are vasoconstrictive, platelet aggregation and further possibly via their effect on glomerular filtration rate through angiotensin converting enzyme (ACE) inhibitors [37] [38]. In this regard, Gottlieb et al. reported that in congestive heart failure, the greatest mortality rate occurred in hypomagnesemic patients and increased $\mathrm{Mg}$ deficiencies seem to be associated with prevalence of essential HT [24].

On the other hand, the involvement of trace metals in the development of the hypertensive process is also still a subject of study. It has been reported that role of metals including $\mathrm{Zn}, \mathrm{Cu}, \mathrm{Mg}$ and $\mathrm{Mn}$ in the serum are important in maintaining BP because their imbalance has been associated with an increased risk of HT and modification of the homeostasis of these metals was considered to occur in essential HT [14] [15]. In this regard, serum level of metal ions is an important indicator of the metal imbalances and their involvement in the pathological process of primary HT. Among the different metal ions, it seems that $\mathrm{Zn}$ is an important metal ion which plays a role in the pathogenesis of essential HT [39]. In interesting studies carried out in HTS patients by Anaelechi et al. [40] a nd Taneja and Mandal [41], it has been revealed that serum Zn levels was found to be increased in HTS patients as compared to normal subjects while other metals were decreased or not statistically different. They further reported that this condition seemed to increase progressively from prehypertensives to those with stage-II HT. It seems that even though the exact role couldn't be properly identified, elevated level of serum Zn may play an aetiological role in subjects with primary HT. In such cases, it is possible that excess serum level of $\mathrm{Zn}$ is thought to cause an increase in intracellular $\mathrm{Zn}$ within the cell which in turn causes a rise of free $\mathrm{Ca}^{2+}$ level in the smooth muscular layer of blood vessels with consequent vasoconstriction, increased peripheral resistance and elevated BP (Figure 1). Further, it is also possible that high Zn level in the blood may interact with more complex systems involved in the leptin secretion, regulation and which in turn may caused an increase in BP by sympathetic nervous system [42]-[44]. Moreover, it has been suggested that an elevated level of $\mathrm{Zn}$ in renal blood may also play role in BP as Zn could favour the activity of carbonic anhydrase, a Zn metalloenzyme and consequently the development of HT via an effect opposite to that of some diuretics or due to high sympathetic nervous activity. Thus, the variations in the concentration of trace metals in blood and increase in BP could be related in some ways to variations in the metabolism of hormones whose essential role in metal homeostasis is well established [45] [46].

In addition to this, high blood Zn level may also lead to elevation in systemic BP in healthy individuals presumably through the oxidative stress caused by superoxide anion $\left(\mathrm{O}_{2}^{-}\right)$[47]. Due to $\mathrm{Zn}-\mathrm{Cu}$ antagonistic interactions in the body, the increased serum $\mathrm{Zn}$ and decreased serum $\mathrm{Cu}$ result in reduction in the activity of SOD leading to oxidative stress causing arterial damage in essential HT [48]. In this regard, more recently the role of the $\mathrm{O}_{2}^{-}$has been examined in relation to endothelial dysfunction related to HT. Nitric oxide ( $\left.\mathrm{NO}^{-}\right)$, a vasodilator can be scavenged by $\mathrm{O}_{2}^{-}$to form peroxynitrite $\left(\mathrm{ONOO}^{-}\right)$which effectively reduce the bioavailability of endothelium-derived NO. Therefore, circumstances that result in increased $\mathrm{O}_{2}^{-}$can be harmful in several ways: first, by removing the beneficial effects of $\mathrm{NO}$, and second, by the damaging effects of $\mathrm{ONOO}^{-}$, which can be protonated to peroxynitrous acid, the cleavage products of which are among the most reactive oxygen species in the biological system [49] [50]. In addition, several studies have demonstrated that $\mathrm{O}_{2}^{-}$can act as a vasoconstrictor [51] [52] (Figure 1).

Besides $\mathrm{Zn}, \mathrm{Cu}$ is an essential metal that plays a critical role in haemoglobin synthesis, immune functions and as a cofactor for $\mathrm{Cu} / \mathrm{Zn}$ superoxide dismutase (Cu-Zn-SOD) and ceruloplasmin in a define range. However, high blood $\mathrm{Cu}$ level is thought to be an independent risk factor for CVD especially myocardial infarction and atherosclerosis [53]. It has been reported that HT is the most common manifestation of hypercupremia. High Cu level in the blood is associated with chronic inflammation as indicated by increased levels of serum C-reactive protein and is an important etiologic factor for HT (Figure 2). Further, due to the strong redox nature of Cu, it catalyzes the production of highly reactive oxygen species which have the potential to cause oxidative damage to proteins, DNA, lipids and other molecules. As a result of this, $\mathrm{Cu}$ overload induces the tissue injuries and which 


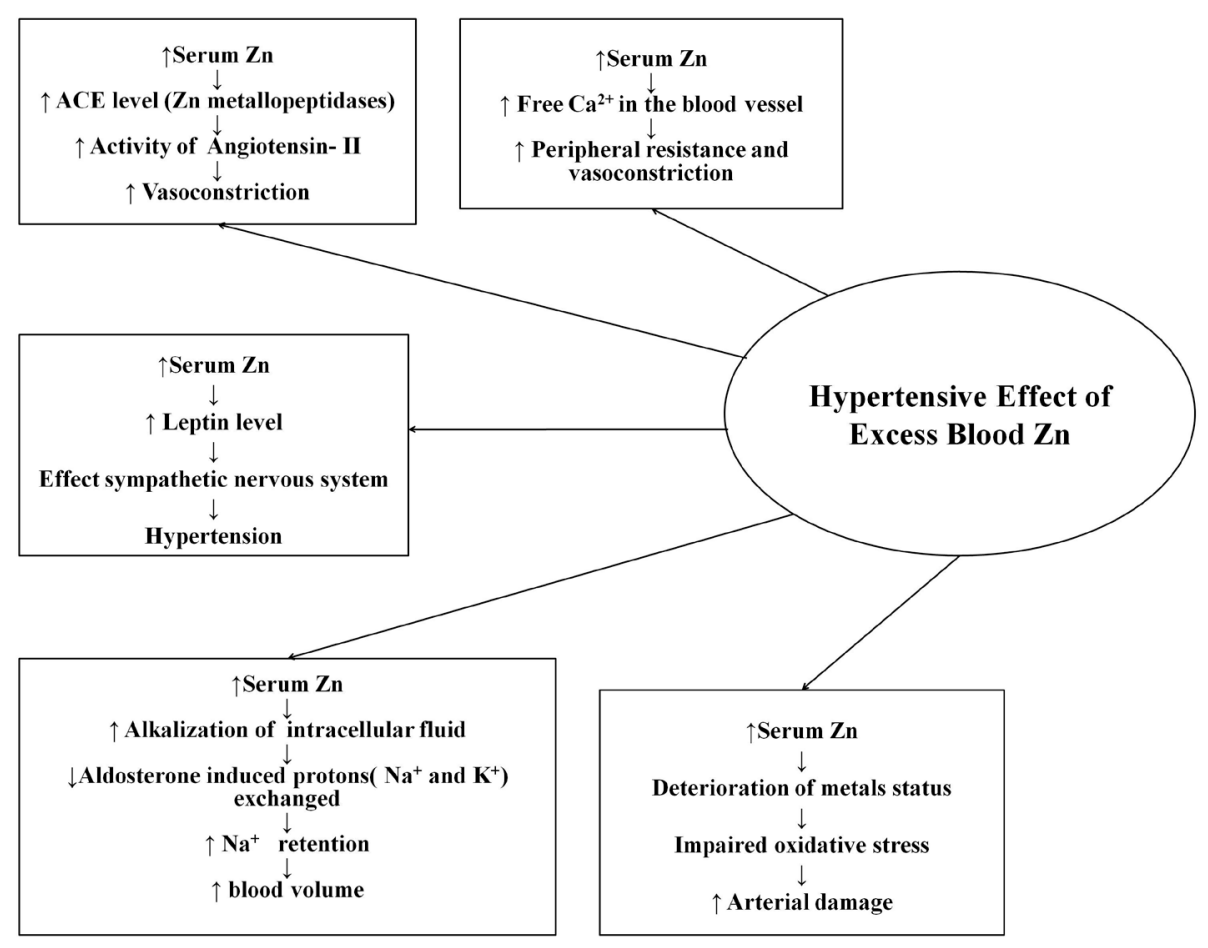

Figure 1. Mechanism of hypertesnive effect of excess $\mathrm{Zn}$ in blood $\uparrow$ : Increase.

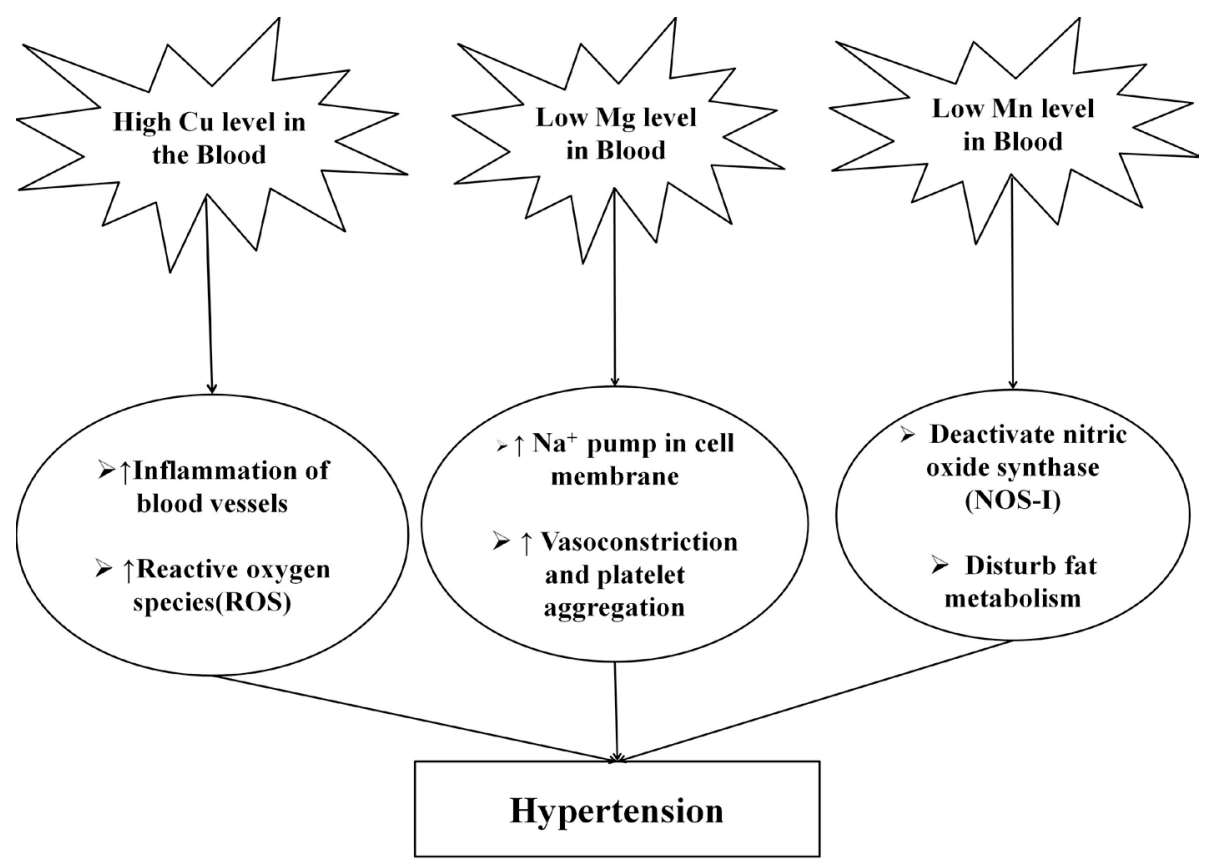

Figure 2. Hypertesnive effects of disparity of $\mathrm{Mg}, \mathrm{Cu}$ and $\mathrm{Mn}$ in blood $\uparrow$ : Increase.

may lead to diseases or affect the progression of HT and other diseases. In this connection, the World Health Organization in 1974 has warned that high levels of $\mathrm{Cu}$ in the tissues are positively correlated with HT [54] [55].

In addition to $\mathrm{Zn}$ and $\mathrm{Cu}$, low blood $\mathrm{Mn}$ level may also be of special pathogenetic importance in regards to the development of HT and very interestingly lower plasma Mn level was also reported to observe in HTS subjects. One of critical role of Mn in the HT is through their role in lipid metabolism as studies have revealed that Mn possess choline-like lipotrophic properties which is known to prevent atherosclerosis and therefore affect lipid 
metabolism in HTS patients [56]. Mn also stimulates hepatic synthesis of cholesterol and fatty acids and hence may be involved in regulating cholesterol levels as related to endogenous synthesis. It is a cofactor for acetyl CoA carboxylase and mevalonic kinase and both enzymes are operative in the metabolic pathway for cholesterol synthesis [57]. Moreover, Mn might also have played an important role in the physiopathological conditions of $\mathrm{HT}$ as it activates nitric oxide synthase (NOS-I), which in turn converts L-arginine into L-citrulline and NO, and produces $\mathrm{O}_{2}^{-}$in the absence of L-arginine which has been implicated HT (Figure 2) [58].

Further, essential HT is associated with greater than normal imbalances in antioxidant status, suggesting that oxidative stress is important in the pathogenesis of essential HT or in arterial damage related to essential HT and where these trace metals have a crucial role to play [59] [60]. Zn, Cu and $\mathrm{Mn}$ are found in almost all oxygen-utilizing cells and are essential for catalyzing reactions for removing the highly reactive $\mathrm{O}_{2}^{--}$because these metals are cofactors of antioxidant enzymes like cytosolic Cu/Zn-SOD, mitochondrial Mn-SOD and extracellular superoxide dismutase (EC-SOD) and they are necessary for maintaining health throughout life [6]-[8]. $\mathrm{Zn}$ and $\mathrm{Cu}$ participation in the control of human HT is supported by their lower bioavailability in HT patients pertaining to Zn and Cu-dependent antioxidant enzymes in HT [22]; [31]. Due to increased molar ratio of Zn to $\mathrm{Cu}$ ratio in the diet and as a consequent of $\mathrm{Zn}-\mathrm{Cu}$ antagonism in the intestinal absorption resulted $\mathrm{Cu}$ deficiency and impairs the oxidative defense system which aggravates the risk for HT in humans [30] [31]. The deficiency of $\mathrm{Cu}$ in hypertensive probably contributes to decreased activities of lysyl oxidase and SOD which result in failure of collagen and elastin cross linking and impaired defence against free radicals [61] [62].

\section{Role of Metals in Rennin-Angiotensin-Aldosterone System (RAAS) Is Linked to Hypertension}

The HT maintains a close relationship with various hormonal systems mainly with the RAAS. There is strong evidence that the RAAS plays an important role in the pathogenesis of essential HT and its complications which in turn is affected by metal ions. Angiotensin converting enzyme (ACE), the most important component of RAAS is usually associated with HT and some reports suggested that ACE may be one of the independent factors affecting HT [12]. Regarding possible mechanisms and role of metal ions considering the RAAS, Zn is observed to be involved, firstly because ACE is a Zn-containing peptide and increased levels of serum Zn were reported to correlate positively with the levels of ACE in HTS patients and secondly Zn take part in arterial pressure regulation by influencing other hormonal systems particularly aldosterone [20] [25] [63]. Modulation of RAAS and inhibition of ACE have long been prime strategies in the treatment of HT. Zn gains importance because ACE is a well-known $\mathrm{Zn}$ metallopeptidase that converts angiotensin-I to the potent vasoconstrictor angiotensin-II and that degrades bradykinin, a powerful vasodilator, that is both for the regulation of vascular tone and cardiac functioning [64]-[66]. Plasma ACE levels were found to be significantly higher in HTS compared to normotesives (NTS) control and they had direct correlations with increased serum Zn levels [25]. Further, the increased level of serum $\mathrm{Zn}$ has been reported to prevent the alkalinization of the intracellular fluid by preventing the aldosterone dependent movement of extracellular $\mathrm{Ca}^{2+}$ ions. As a result of that the aldosterone induced proton influx is significantly reduced in the presence of $\mathrm{Zn}$. The excess $\mathrm{Zn}$ in blood serum of HT patients in the present study may contribute to a continuous acidification caused by $\mathrm{Zn}$ in the vicinity of $\mathrm{K}^{+}$ion channel of the epithelial cells and promotes the transmembrane conductance of $\mathrm{Na}^{+}$ion and $\mathrm{K}^{+}$ion without the exchange of proton. The retention of proton does not allow the feedback mechanism in switching off the release of aldosterone from zonaglomerulosa. As a result of that the aldosterone level continuous to build up in HT patients, which in turn makes the blood hyperosmotic due to the excessive absorption of $\mathrm{Na}^{+}$ions and loss of $\mathrm{K}^{+}$ions. The hyperosmotic blood permits the retention of water resulting in the increase in total volume finally leading to HT [67]-[69]. Oxidative stress is the other factor that influence the activity of $\mathrm{Na}^{+} / \mathrm{Li}^{+}$exchanger, $\mathrm{Na}^{+} / \mathrm{H}^{+}$exchanger (NHE) and $\mathrm{Na}^{+} / \mathrm{K}^{+}$ATP-ase associated with essential HT [70].

In addition to this, it has been reported that the Mg homeostasis is regulated by RAAS and which is an important linked to the role of Mg status to the aetiology of HT [71]. Increased serum levels of both Mg and Mn are also reported in hypertensive patients [26] [27]. Hypermagnesaemia is observed to be associated with increase in Mg excretions in the urine due to an increase in the filtered load and its reduced re-absorption in nephrons and results in Mg-deficiency in HT patients [23]. The proposed mechanisms of Mg action on BP involve renal vasodilatation, prostacyclin release and acceleration of the cell membrane sodium pump [72] [73]. When dealing with specific HT patients, defects in Mg metabolism are found in young people having borderline HT, whereas Mg treatment lowers the blood pressure in patients with malignant HT [74]. 


\section{Epidemiological Data on the Metals Status in the Hypertensive Patients in India Consuming Zn Rich Diet}

The recent survey on trace metals status of different vegetables in State of Punjab around Chandigarh as reported by Punjab State Pollution Control Board revealed that the $\mathrm{Zn}$ level is significantly higher $(40 \mathrm{mg} / \mathrm{kg}$ or more in above ground vegetables and $120 \mathrm{mg} / \mathrm{kg}$ or above in underground vegetables) in underground water irrigated vegetables due to its excessive use in agricultural and husbandry practices but the levels of $\mathrm{Cu}$ and $\mathrm{Mg}$ are found to be within prescribed limit [75]. In a similar way, high $\mathrm{Zn}$ level but normal $\mathrm{Cu}$ and $\mathrm{Mn}$ levels are also observed in the vegetables and meat foodstuffs frequently consumed by the living population of Manipur, India [76]. It can be concluded from the above review that presence some metals in organism influence to the concentration other metals and therefore correct proportion of concentrations between individuals metals were important for proper physiological accomplishment of metals in the body [77]. In this regard, blood is considered the medium of transport of metals in the body and provides direct evidence about their concentrations and therefore, considered as a good indicator of the current body burden of the metals [34]. An epidemiological study conducted in the population of Manipur, India consuming $\mathrm{Zn}$ rich diet showed an increased serum $\mathrm{Zn}, \mathrm{Mg}$ and Mn levels and decreased serum Cu levels in the HTS patients as compared to NT control (Table 1). In this regards, Tubek in 2001 [78] and Davydenko et al., in 1995 [79] observed increased absorption of Zn from the alimentary tract in primary arterial HT as hyperzincemia was observed in HTS individuals with or without complications. They have suggested that high level of Zn was related with high level of arterial HT. Further blood tends to maintain $\mathrm{Zn}$ homeostasis either by increasing or decreasing $\mathrm{Zn}$ excretion in the urine depending upon Zn intake [21]. In the present study, increased urinary Zn excretion revealed its high intake or higher absorption rate in genetically predisposed HTS subjects (Table 1). $\mathrm{Zn}-\mathrm{Cu}$ antagonism results when increased molar ratio of $\mathrm{Zn}$ to $\mathrm{Cu}$ used in the diet that leads in C deficiency in humans that further impairs the oxidative defense system and aggravates the risk for HT [30] [31]. The low level of $\mathrm{Cu}$ in serum and its higher excretion observed during present epidemiological study appears to occur because of two reasons. Firstly, reduction of $\mathrm{Cu}$ absorption at the intestinal level caused by $\mathrm{Zn}-\mathrm{Cu}$ antagonism due to high $\mathrm{Zn}$ absorption as displayed by presence of hyperzincemia and hypocupereria and secondly, a high rate of $\mathrm{Cu}$ excretion in the urine. The excessive loss of $\mathrm{Cu}$ resulted in deficiency of $\mathrm{Cu}$ which may contribute to HT in the present study [29]. This is in conformity with earlier report that excessive $\mathrm{Zn}$ in diet of rat causes leaching of $\mathrm{Cu}$ and $\mathrm{Mg}$ from the tissues into the blood plasma. Their levels in serum were elevated while their concentration in tissues fell significantly and rats become hypertensive [80]. Low plasma concentration of $\mathrm{Cu}$ has been reported to modify the activity of $\mathrm{Na}^{+}$transporting systems in the erythrocyte membranes due to oxidative stress [68]. Increased urinary $\mathrm{Cu}$ in the HTS patients correlated positively with systolic and diastolic pressures but an inverse relationship between serum $\mathrm{Cu}$ and diastolic pressure suggested that $\mathrm{Cu}$ bioavailability might be reduced involved in BP regulation as suggested by many workers $\mathrm{Mg}$ deficiencies were also evaluated to relate with essential HT [25]. Resnick et al. [71] also suggested that Mg and Ca homeostasis may be regulated by the RAAS. Mg and its interactions with other cations may play important role in the pathogenesis of essential HT. Extracellular Mg concentration affects cellular intake, binding, and distribution of $\mathrm{Ca}^{2+}$ in vascular smooth muscle. Mg's effect on the vasculature is opposite to $\mathrm{Ca}^{2+}$ as $\mathrm{Mg}$ is found primarily intracellular, unlike $\mathrm{Ca}^{2+}$, which is extracellular. In hypertension, intracellular free $\mathrm{Mg}$ falls, $\mathrm{Ca}^{2+}$ is elevated [81]. Therefore, the regulatory role of $\mathrm{Mg}$ on peripheral vascular resistance may have an important role in $\mathrm{Ca}^{2+}$ uptake and thus in HT [25]. Hypermagnesaemia is also associated with increase in magnesium excretion due to an increase in the filtered load and reduced re-absorption in TALH [23] and results in Mg-deficiency as increased urinary Mg level observed during the present study.

\section{Conclusions and Future Directions}

From published literature, it could be concluded that normal levels of metals are disturbed in HTS patients. The present review also indicates that imbalance of metals like $\mathrm{Zn}, \mathrm{Cu}, \mathrm{Mg}$ and $\mathrm{Mn}$ in the body may influence the incidences of HT however the involvement may be primary or secondary to some other cases. Disturbances of these metals in the blood result in the deterioration of normal physiological process of the body related with HT and finally lead to increase in BP. Experimental evidence also corroborates the idea that imbalances of metal ions are associated with the aetiology of HT. The present epidemiological studies indicate that the change in body metal homeostasis is prevalent in population of Manipur suffering from HT which may be due to consumption of Zn rich diet in this region. These metal imbalances may be a triggering factor for the development of HT 
Table 1. Mean serum and urinary $\mathrm{Zn}, \mathrm{Cu}, \mathrm{Mg}$ and $\mathrm{Mn}$ levels and systolic blood pressure and diastolic blood pressure in the normotensives (NT) control and hypertensives (HTS) patients in the Manipur, India population consuming Zn-rich diet.

\begin{tabular}{|c|c|c|}
\hline \multirow{2}{*}{ Parameters } & \multicolumn{2}{|c|}{ Study Subjects } \\
\hline & NT (Control) & HTS (patients) \\
\hline Number & 120.0 & 120.0 \\
\hline Mean age & $47.84 \pm 0.76$ & $45.54 \pm 0.86$ \\
\hline Serum $\mathrm{Zn}^{*}$ & $0.177 \pm 0.01$ & $0.66 \pm 0.01^{\mathrm{a}}$ \\
\hline Serum $\mathrm{Cu}^{*}$ & $0.093 \pm 0.01$ & $0.075 \pm 0.01^{\mathrm{NS}}$ \\
\hline Serum $\mathrm{Mg}^{*}$ & $0.24 \pm 0.01$ & $0.66 \pm 0.04^{\mathrm{a}}$ \\
\hline Serum $\mathrm{Mn}^{*}$ & $2.54 \pm 0.01$ & $3.09 \pm 0.09^{\mathrm{a}}$ \\
\hline Urine $\mathrm{Zn}^{*}$ & $0.180 \pm 0.01$ & $0.369 \pm 0.01^{\mathrm{a}}$ \\
\hline Urine $\mathrm{Cu}^{*}$ & $2.70 \pm 0.10$ & $5.14 \pm 0.15^{\mathrm{a}}$ \\
\hline Urine $\mathrm{Mg}^{*}$ & $0.24 \pm 0.03$ & $0.75 \pm 0.04^{\mathrm{a}}$ \\
\hline Urine $\mathrm{Mn}^{*}$ & $1.32 \pm 0.07$ & $1.87 \pm 0.06^{\mathrm{a}}$ \\
\hline Systolic Blood Pressure ${ }^{@}$ & $140.66 \pm 1.00$ & $160.66 \pm 1.21^{\mathrm{a}}$ \\
\hline Diastolic Blood Pressure ${ }^{@}$ & $83.16 \pm 0.65$ & $93.16 \pm 0.81^{\mathrm{a}}$ \\
\hline
\end{tabular}

in this population. However, in future large sample sizes epidemiological studies on serum and urinary analysis of various essential metals, may help to have scientific as well as practical implications in understanding for their long term adverse effects. This study would also be helpful to investigate the complex relationship between serum metals status and HT because a single metal does not result in a universal effect on BP, however, interactions between various metals and systems may affect regulation of BP. The results of this study also provided guideline to the other researchers investigating the role of metals in the disease. However, more studies including other metals in different biological samples should be conducted to explore the potential relationship between metals imbalance and the development of HT. Future epidemiological and clinical studies should take account of other information like daily dietary intakes and factors like obesity in order to understand the clearer picture of HT mechanism.

\section{Acknowledgements}

The author gratefully acknowledged to University Grant Commission (UGC), Government of India, New Delhi for providing financial assistance under JRF/SRF Scheme. Also acknowledged the helps rendered by Staffs of Department of Life Sciences, Manipur University, Canchipur, Imphal and Regional Institute of Medical Science and Research (RIMS), Imphal, Manipur during collection of samples.

\section{References}

[1] Kasper, D.L., Braunwald, E., Fauci, A.S., Hauser, S.L., Longo, D.L. and Jameson, J.L. (2005) Harrisons Principles of Internal Medicine. McGraw Hill, New York.

[2] Global Burden of Disease Study (2010) A Comparative Risk Assessment of Burden of Disease and Injury Attributable to 67 Risk Factors and Risk Factor Clusters in 21 Regions, 1990-2010: A Systematic Analysis for the Global Burden of Disease Study 2010. Lancet, 380, 2224-2260.

[3] Noncommunicable Diseases Country Profiles 2011. http://www.who.int/nmh/countries/ind_en.pdf

[4] Gupta, R. (2004) Trends in Hypertension Epidemiology in India. Journal of Human Hypertension, 18, 73-78. http://dx.doi.org/10.1038/sj.jhh.1001633 
[5] Martín-Timón, I., Sevillano-Collantes, C., Segura-Galindo, A. and del Cañizo-Gómez, F.J. (2014) Type 2 Diabetes and Cardiovascular Disease: Have All Risk Factors the Same Strength? World Journal of Diabetes, 5, 444-470. http://dx.doi.org/10.4239/wjd.v5.i4.444

[6] Loyke, H.F. (2002) Effect of Elements in Human Blood Pressure Control. Biological Trace Element Research, 85, 193-209. http://dx.doi.org/10.1385/BTER:85:3:193

[7] Modupe, F.A., Samuel, S.A., Julius, B.F., Beatrice, O.E.O., Abiola, O.A., Emmanuel, O.A. and Racheal, A.T. (2014) Evaluation of Elements in the Pathogenesis of Hypertension in Nigerians. International Journal of Pharmaceutical Sciences Review and Research, 4, 1-2.

[8] Pasha, Q., Malik, S.A., Shaheen, N. and Shah, M.H. (2010) Investigation of Trace Metals in the Blood Plasma and Scalp Hair of Gastrointestinal Cancer Patients in Comparison with Controls. Clinica Chimica Acta, 411, 531-539. http://dx.doi.org/10.1016/j.cca.2010.01.010

[9] Feinendegen, L.E. and Kasperek, K. (1980) Medical Aspects of Trace Element Research. In: Bratter, P. and Schramel, P., Eds., Trace Element Analytical Chemistry in Medicine and Biology, Walterde Gruyter, Berlin.

[10] Giacconi, R., Caruso, C., Malavolta, M., Lio, D., Balistreri, C.R., Scola, L., Candore, G., Muti, E. and Mocchegiani, E. (2008) Pro-Inflammatory Genetic Background and Zinc Status in Old Atherosclerotic Subjects. Ageing Research Review, 7, 306-318. http://dx.doi.org/10.1016/j.arr.2008.06.001

[11] Ilyas, A., Ahmad, H. and Shah, M.H. (2015) Comparative Study of Elemental Concentrations in the Scalp Hair and Nails of Myocardial Infarction Patients versus Controls from Pakistan. Biological Trace Element Research, 166, 123135. http://dx.doi.org/10.1007/s12011-015-0259-x

[12] Taittonen, L., Nuutinen, M., Rasanen, I.M., Mussalo-Rauhamaa, H., Turtinen, J. and Uhari, M. (1997) Lack of Association between Copper, Zinc, Selenium and Blood Pressure among Healthy Children. Journal Human Hypertension, 11, 429-433. http://dx.doi.org/10.1038/sj.jhh.1000466

[13] Edward, J.R., Giffard, R.W. and Aldermand, M.D. (1993) The Fifth Report of the Joint National Committee on Detection, Evaluation and Treatment of High Blood Pressure (JNCV). Archives of Internal Medicine, 153, 154-183. http://dx.doi.org/10.1001/archinte.1993.00410020010002

[14] Liu, W.M., Zhu, Z.G. and Leng, H.X. (2004) Analysis of the Contents of K, Na, Ca, Mg, Zn, Cu, Fe and Mn in Serum of Middle and Old-Aged Hypertension Patients. Guang Pu Xue Yu Guang Pu Fen Xi, 24, 360-362.

[15] Loyke, H.F.L. (1991) Copper and Zinc in Experimental Hypertension. Biological Trace Element Research, 29, 45-49. http://dx.doi.org/10.1007/BF03032673

[16] Hajjar, I. and Kotchen, T. (2003) Regional Variations of Blood Pressure in the United States Are Associated with Regional Variations in Dietary Intakes: The NHANES-III Data. Journal of Nutrition, 133, 211-214.

[17] Fridovich, I. and Freeman, B. (1986) Antioxidant Defense in the Lung. Annual Review of Physiology, 48, 693-702. http://dx.doi.org/10.1146/annurev.ph.48.030186.003401

[18] Marklund, S.L., Holme, E. and Hellner, L. (1982) Superoxide Dismutase in Extracellular Fluids. Clinica Chimica Acta, 126, 41-51. http://dx.doi.org/10.1016/0009-8981(82)90360-6

[19] Lopez, C., Occon, D.C., Mengo, M.S. and Frasquet, D.V.A. (1991) Study of Zinc and Copper Serum Levels in Dislipedimia. Therapies, 46, 17-20.

[20] Ripa, S. and Ripa, R. (1994) Zinc and Arterial Pressure. Minerva Medicine, 85, 455-459.

[21] Lee, D.Y., Prasad, A.S., Hydrick-Adair, C., Brewer, G. and Johnson, P.E. (1993) Homeostasis of Zinc in Marginal Human Zinc Deficiency: Role of Absorption and Endogenous Excretion of Zinc. Journal of Laboratory and Clinical Medicine, 122, 549-556.

[22] Vivoli, G., Bergomi, M., Roverti, S., Pinotiti, M. and Caselgrands, E. (1995) Zinc, Copper and Zinc-Or copper-Dependent Enzymes in Human Hypertension. Biological Trace Element Research, 49, 97-103. http://dx.doi.org/10.1007/BF02788959

[23] Swaminathan, R. (2003) Magnesium Metabolism and Its Disorders. Clinical Biochemical Review, 24, 47-66.

[24] Gottlieb, S.S., Fisher, M.L., Pressel, M.D., Pattern, R.D., Weinberg, M. and Greenberg, N. (1993) Effects of Intravenous Magnesium Sulfate on Arrhythmias in Patients with Congestive Heart Failure. American Heart Journal, 125, 1646-1650. http://dx.doi.org/10.1016/0002-8703(93)90754-W

[25] Ekmekci, O.B., Donma, O. and Tunckale, A. (2003) Angiotensin-Converting Enzyme and Metals in Untreated Essential Hypertension. Biological Trace Element Research, 95, 203-110. http://dx.doi.org/10.1385/BTER:95:3:203

[26] He, B.P., Li, D.F., Ma, J.W., Chen, J., Liu, X.Y., Zhang, X.R. and Xu, J.M. ( 2004) Determination of Trace Copper and Zinc in Hypertension Complicated with Hyperlipemia by Atomic Absorption Spectrophotometry. Guang Pu Xue Yu Guang Pu Fen Xi, 24, 741-743. 
[27] Tang, Y.R., Zhang, S.Q., Xiong, Y., Zhao, Y., Fu, H., Zhnag, H.P. and Xiong, K.M. (2003) Studies of Five Microelements Contents in Human Serum, Hair, and Fingernails Correlated with Aged Hypertension and Coronary Heart Disease. Biological Trace Element Research, 92, 97-104. http://dx.doi.org/10.1385/BTER:92:2:97

[28] Yanagisawa, H., Sato, M., Nodera, M. and Wada, O. (2004) Excessive Zinc Intake Elevates Systemic Blood Pressure Levels in Normotensive Rats-Potential Role of Superoxide-Induced Oxidative Stress. Journal of Hypertension, 22, 543-550. http://dx.doi.org/10.1097/00004872-200403000-00017

[29] Klevay, L.M. (1987) Hypertension in Rats due to Copper Deficiency. Nutrition Report International, 35, 999-1005.

[30] Sandstead, H.H. (1995) Requirements and Toxicity of Essential Trace Elements, Illustrated by Zinc and Copper. American Journal of Clinical Nutrition, 61, 621-624.

[31] Allen, G.D. and Klevay, L.M. (1994) Copper: An Antioxidant Nutrient for Cardiovascular Health. Current Opinion in Lipidology, 5, 22-28. http://dx.doi.org/10.1097/00041433-199402000-00005

[32] Kazi, T.G., Afridi, H.I., Kazi, N., Jamali, M.K., Arain, M.B., Jalbani, N. and Kandhro, G.A. (2008) Copper, Chromium, Manganese, Iron, Nickel, and Zinc Levels in Biological Samples of Diabetes Mellitus Patients. Biological Trace Element Research, 122, 1-18. http://dx.doi.org/10.1007/s12011-007-8062-y

[33] Fraga, C.G. (2005) Relevance, Essentiality and Toxicity of Trace Elements in Human Health. Molecular Aspects of Medicine, 26, 235-244. http://dx.doi.org/10.1016/j.mam.2005.07.013

[34] Lutsenko, S., Barnes, N.L., Bartee, M.Y. and Dmitriev, O.Y. (2007) Function and Regulation of Human Copper-Transporting ATPases. Physiologocal Review, 87, 1011-1046. http://dx.doi.org/10.1152/physrev.00004.2006

[35] Saltman, P. (2007) Trace Elements and Blood Pressure. Annals of Internal Medicine, 2, 23-26.

[36] Altura, B.T. and Altura, B.M. (1987) Cardiovascular Actions of Magnesium. Magnesium Bulletin, 9, 6-21.

[37] Sanb, T.T. (1994) Consequences of Magnesium Deficiency on the Enhancement of Stress Reactions, Preventive and Therapeutic Implications. Journal College Nutrition, 13, 429-446. http://dx.doi.org/10.1080/07315724.1994.10718432

[38] Stevenson, R.N., Keywood, C., Amadi, A. and Davies, D.J. (1991) Angiotensin Converting Enzyme Inhibitors and Conservation in Patients with Congestive Heart Failure. British Heart Journal, 66, 19-21. http://dx.doi.org/10.1136/hrt.66.1.19

[39] Momtaz, M., Mughal, N., Siddique, A. and Mahboob, T. (2000) Changes in Blood Levels of Trace Elements and Electrolytes in Hypertensive Patients. Medical Journal of the Islamic Republic of Iran, 14, 115-118.

[40] Anaelechi, J.O., Olugbenga, E.A., Olubunmi, G.A., Madu, J.O., Rasheeda, A.A., Ubuo, K.M. and Isaac, L.U. (2013) Evaluation of Selected Trace Metals in Some Hypertensive Subjects in a Tertiary Health Institution in Southwest Nigeria. Biokemistri, 25, 6-12.

[41] Taneja, S.K. and Mandal, R. (2007) Mineral Factors Controlling Essential Hypertension—A Study in the Chandigarh, India Population. Biological Trace Element Research, 120, 61-73. http://dx.doi.org/10.1007/s12011-007-8013-7

[42] Baltaci, A.K., Mogulkov, R. and Halifeoglu, I. (2005) Effects of Zn Deficiency and Supplementation on Plasma Leptin Levels in Rats. Biological Trace Element Research, 104, 36-41. http://dx.doi.org/10.1385/BTER:104:1:041

[43] Rayner, D.V. and Trayhurn, P. (2001) Regulation of Leptin Production: Sympathetic Nervous System Interactions. Journal of Molecular Medicine, 79, 8-20. http://dx.doi.org/10.1007/s001090100198

[44] Haynes, W.G., Sivitz, W.I., Morgan, D.A., Walsh, S.A. and Mark, A.L. (1997) Sympathetic and Cardiorenal Actions of Leptin. Hypertension, 30, 614-619. http://dx.doi.org/10.1161/01.HYP.30.3.619

[45] Frithz, G. and Ronquist, G. (1979) Increased Red Cell Content of Zn in Essential Hypertension. Acta Medica Scandinavica, 205, 647-649. http://dx.doi.org/10.1111/j.0954-6820.1979.tb06120.x

[46] Leblondel, G. and Allain, P. (1988) Altered Element Concentrations in Tissues of Spontaneously Hypertensive Rats. Biomed Pharmacother, 42, 121-129.

[47] Yanagisawa, H., Sato, M., Nodera, M. and Wada, O (2004) Excessive Zinc Intake Elevates Systemic Blood Pressure Levels in Normotensive Rats-Potential Role of Superoxide-Induced Oxidative Stress. Journal of Hypertension, 22, 543-550. http://dx.doi.org/10.1097/00004872-200403000-00017

[48] Russo, C., Olivievi, O., Girelli, D., Faccini, G., Zenari, M., Lombardi, S. and Corrocher, R. (1998) Antioxidant Status and Lipid Peroxidation in Patients with Essential Hypertension. Journal of Hypertension, 16, 1267-1271。 http://dx.doi.org/10.1097/00004872-199816090-00007

[49] Rubanyi, G.M. and Vanhoutte, P.M. (1986) Superoxide Anions and Hyperoxia Inactivation Endothelium-Derived Relaxing Factor. American Journal of Physiology, 250, 822-827.

[50] Beckman, J.S., Chen, J., Ischiropoulos, H. and Crow, J.P. (1994) Oxidative Chemistry of Peroxynitrite. In: Packer, L., Ed., Methods of Enzymology, Academic Press Inc, San Diego, 229-240. http://dx.doi.org/10.1016/s0076-6879(94)33026-3 
[51] Auch-Schwelk, W., Katusic, Z.S. and Vanhoutte, P.M. (1989) Contractions to Oxygen-Derived Free Radicals Are Augmented in Aorta of the Spontaneously Hypertensive Rat. Hypertension, 13, 859-864.

http://dx.doi.org/10.1161/01.HYP.13.6.859

[52] Cosentino, P.M., Sill, J.C. and Katusic, Z.S. (1994) Role of Superoxide Anions in the Mediation of Endothelium- Dependent Concentrations. Hypertension, 23, 229-235. http://dx.doi.org/10.1161/01.HYP.23.2.229

[53] Kinsman, G.D., Howard, A.N., Stone, D.L. and Mullins, P.A. (1990) Studies in Copper Status and Atherosclerosis. Biochemical Society Transaction, 18, 1186-1188. http://dx.doi.org/10.1042/bst0181186

[54] Cebi, A., Kaya, Y., Gungor, H., Demir, H., Yoruk, I.H., Soylemez, N., Gunes, Y and Tuncer, M. (2011) Trace Elements, Heavy Metals and Vitamin Levels in Patients with Coronary Artery Disease. International Journal of Medical Sciences, 8, 456-460. http://dx.doi.org/10.7150/ijms.8.456

[55] Kang, Y.J. (2011) Copper and Homocysteine in Cardiovascular Diseases. Pharmacological Therapeutics, 129, 321331. http://dx.doi.org/10.1016/j.pharmthera.2010.11.004

[56] Henzel, J.H., Holtmann, B., Keitzer, F.W., DeWeese, M.S. and Lichti, E (1967-1968) Trace Elements in Atherosclerosis, Efficacy of Zinc Medication as a Therapeutic Modality. In: Proceedings of the 2nd Conference on Trace Substances in Environmental Health.

[57] Lynen, F. (1972) The Role of Biotin-Dependent Carboxylations in Biosynthetic Reactions. Biochemical Journal, 102, 381-400. http://dx.doi.org/10.1042/bj1020381

[58] Weaver, J., Porasuphatana, S., Tsai, P. and Cao, G.L. (2004) The Effect of Divalent Cations on Neuronal Nitric Oxide Synthase Activity. Toxicological Sciences, 81, 325-331. http://dx.doi.org/10.1093/toxsci/kfh211

[59] Carla, R., Oliviero, O., Domenico, G., Giovanni, F., Maria, Z., Sara, L. and Roberto, C. (1998) Antioxidant Status and Lipid Peroxidation in Patients with Essetial Hypertension. Journal of Hypertension, 16, 1267-1271. http://dx.doi.org/10.1097/00004872-199816090-00007

[60] Vivoli, G., Borella, P., Bergomi, M. and Fantuzzi, G. (1987) Zinc and Copper Levels in Serum, Urine, and Hair of Humans in Relation to Blood Pressure. Science of Total Environment, 66, 55-64. http://dx.doi.org/10.1016/0048-9697(87)90077-5

[61] Lesile, M.K. (2000) Cardiovascular Disease from Copper Deficiency-A History. Journal of Nutrition, 130, 489S492S.

[62] Bergomi, M., Rovesti, S., Vincent, M., Vivoli, R., Caselgrandi, E. and Vivoli, G. (1997) Zinc and Copper Status and Blood Pressure. Journal of Trace Element Medical Biology, 11, 166-169. http://dx.doi.org/10.1016/S0946-672X(97)80047-8

[63] Bakhle, Y. and Reynard, A. (1971) Characteristics of the Angiotensin I Converting Enzyme from Dog Lung. Nature New Biology, 229, 187-189. http://dx.doi.org/10.1038/newbio229187a0

[64] Baudin, B. (2002) New Aspects on Angiotensin-Converting Enzyme: From Gene to Disease. Clinical Chemistry Laboratory Medicine, 40, 256-265. http://dx.doi.org/10.1515/CCLM.2002.042

[65] Turner, A.J. and Hooper, N.M. (2002) The Angiotensin-Converting Enzyme Gene Family: Genomics and Pharmacology. Trends of Pharmacology Science, 23, 177-183. http://dx.doi.org/10.1016/S0165-6147(00)01994-5

[66] Corvol, P., Michaud, A., Soubrier, F. and Williams, T.A. (1995) Recent Advances in Knowledge of the Structure and Function of the Angiotensin-Converting Enzyme. Journal Hypertension, 13, 3-10. http://dx.doi.org/10.1097/00004872-199509003-00002

[67] Gekle, M., Golenhofen, N., Oberleithner, H. and Silbernagl, S. (1996) Rapid Activation of $\mathrm{Na}^{+} / \mathrm{H}^{+}$Exchange by Aldosterone in Renal Epithelial Cells Requires $\mathrm{Ca}^{2+}$ and Stimulation of a Plasma Membrane Proton Conductance, Proceeding of the National Academy of Science of the United States of America, 93, 10500-10504. http://dx.doi.org/10.1073/pnas.93.19.10500

[68] Gekle, M., Silbernagl, S. and Obserleithner, H (1997) The Mineralocorticoid Aldosterone Activates a Proton Conductance in Cultured Kidney Cells. American Journal of Physiology, 273, 1673-1678.

[69] Kędzierska, K., et al. (2005) Trace Elements Modify the Activity of Sodium Transporting System in Erythrocyte Membrane in Patients with Essential Hypertension-Preliminary Study. Nephrology Dialysis Transplantation, 20, 469-471. http://dx.doi.org/10.1093/ndt/gfh613

[70] Semplicini, A., Canessa, M., Mozzato, M.G., Ceolotto, G., Marzola, M., Buzzaccarini, F., Casolino, P. and Pessina, A.C. (1989) Red Blood Cell $\mathrm{Na}^{+} / \mathrm{Hand}^{+} / \mathrm{Na}^{+}$Exchanges in Patients with Essential Hypertension. American Journal of Hypertension, 2, 903-908.

[71] Resnick, L., Nocholson, J. and Laragh, J. (1985) Calcium Metabolism and Renin-Aldosterone System in Essential Hypertension. Journal of Cardiovascular Pharmacology, 7, 187-193.

http://dx.doi.org/10.1097/00005344-198500076-00033 
[72] Rude, R., Mannoogian, C. and Ehrlich, L. (1989) Mechanics of Blood Pressure Regulation by Magnesium in Man. Magnesium, 8, 266-273.

[73] Saito, K., Hattori, K. and Omatsu, T. (1988) Effects of Oral Magnesium on Blood Pressure and Red Cell Sodium Transport in Patients Receiving Long-Term Thiazide Diuretics for Hypertension. American Journal of Hypertensions, 1, 71S-74S. http://dx.doi.org/10.1093/ajh/1.3.71S

[74] Fujita, T., Ito, Y., Ando, K., Noda, H. and Ogata, E. (1990) Attenuated Vasodilator Response to $\mathrm{Mg}^{2+}$ in Young Patients with Borderline Hypertension. Circulation, 82, 384-393. http://dx.doi.org/10.1161/01.CIR.82.2.384

[75] Ram, B., Garg, S.P. and Matharu, S.S. (2005) Effect of Contaminants in Wastewater on Soil and Vegetables-A Case Study. Panjab Pollution Control Board.

[76] Singh, K.B. and Taneja. K. (2010) Concentration of Zn, Cu and Mn in Vegetables and Meat Foodstuffs Commonly Available in Manipur: A North Eastern State of India. Electronic Journal of Environmental Agricultural and Food Chemistry, 9, 610-616.

[77] Nowak, B. and Chmielnicka, J. (2000) Relationship of Lead and Cadmium to Essential Elements in Hair, Teeth, and Nails of Environmentally Exposed People. Ecotoxicology and Environmental Safety, 46, 265-274. http://dx.doi.org/10.1006/eesa.2000.1921

[78] Tubek, S (2001) Increased Absorption of Zinc from Alimentary Tract in Primary Arterial Hypertension. Biological Trace Element Research, 83, 31-38. http://dx.doi.org/10.1385/BTER:83:1:31

[79] Davydenko, N.V., Smirnova, I.P., Kvasha, E.A., Gorbas, I.M. and Koblians, K.A.V. (1995) Interrelationship between Dietary Intake of Minerals and Prevalence of Hypertension. Voprosy Pitaniia, 6, 17-19.

[80] Taneja, S.K., Mandal, R. and Girhotra, S. (2006) Long Term Excessive Zn-Supplementation Promotes Metabolic Syndrome-X in Wistar Rats Fed Sucrose and Fat Rich Semi Synthetic Diet. Indian Journal of Experimental Biology, 44, 705-718.

[81] Lim, R. and Herzog, W. (1998) Magnesium for Cardiac Patients. Contemporary Internal Medicine, 10, 6-9.

\section{Submit or recommend next manuscript to SCIRP and we will provide best service for you:}

Accepting pre-submission inquiries through Email, Facebook, Linkedin, Twitter, etc

A wide selection of journals (inclusive of 9 subjects, more than 200 journals)

Providing a 24-hour high-quality service

User-friendly online submission system

Fair and swift peer-review system

Efficient typesetting and proofreading procedure

Display of the result of downloads and visits, as well as the number of cited articles

Maximum dissemination of your research work

Submit your manuscript at: http://papersubmission.scirp.org/ 